\title{
SÕNARAAMATU KOHTULINGVISTILINE ANALÜÜS: EESTI PRETSEDENT
}

\author{
Margit Langemets, Piret Voll
}

\begin{abstract}
Ülevaade. 2003. aastal viidi Eestis esimest korda läbi kohtulingvistiline leksikograafiaekspertiis, mille käigus hinnati mitme sõnaraamatu sisu, lähtudes kriminaalsüüdistusest intellektuaalse omandi varguses. Artiklis kirjeldatakse Eesti Keele Instituudis läbi viidud leksikograafiaekspertiisi ja selle jaoks välja töötatud keeletehnoloogilist meetodit. Ekspertiisi tulemuste põhjal on välja pakutud piirmäär kakskeelsete sõnaraamatute originaalsuse üle otsustamiseks. Käsitletav juhtum on Eestis ainulaadne, kujutades säärasena kohtulingvistilist pretsedenti.
\end{abstract}

Võtmesõnad: kohtulingvistika, leksikograafiaekspertiis, sõnaraamatud, inglise keel, eesti keel

\section{Sissejuhatus: kohtulingvistikast ja sõnaraamatuplagiaadist}

Eestis on kohtulingvistika pea tundmatu ala. Keeleekspertiisi on vajatud enamasti solvangut või laimu käsitlevate kohtuasjade juures. Kohtulingvistika tegelik töömaa on palju avaram, hõlmates nii õiguskeelt kui praktiliselt kõike, mis seondub keele ja kohtusüsteemi ning seadusandlusega (McMenamin 2002: 67). Enamasti uurivad kohtulingvistika eksperdid keelekasutust nii foneetiliselt kui ka stilistiliselt seoses laimujuhtumitega, nii on pea võimatuks osutunud leida leksikograafiapretsedenti. Autoriõigus ja plagiaatlus on kohtulingvistikas suhteliselt uued teemad üldse, mitte ainult Eestis, vaid ka mujal. Leksikograafiaalase seadusandluse puudumise üle on kurtnud näiteks Suurbritannia leksikograaf John Williams (1992: 566).

Iseenesest on sõnaraamatute pärast kohtuteed käidud juba 18. sajandil. Londonist on teada juhtum, milles plagiaatluses süüdistati Ann Fisheri sõnaraamatut "An Accurate New Spelling Dictionary and Expositor of the English Language". Leiti, et teos võib olla kopeeritud John Enticki "The New Spelling Dictionary" (1765) pealt. Võrdlus näitas, et üks-ühele oli üle võetud 43,5\%. Kaks aastat kestnud kohtuvaidluste tulemusel lubati sõnaraamat siiski 1773. aastal välja anda (Rodriguez-Alvarez 
2006). Veel varasem, mitte küll kohtusse jõudnud näide on pärit 17. sajandist, kui Londonis ilmus Guy Miège’i “The Great French Dictionary. In Two Parts” (1688). Abel Boyer andis 1699. aastal välja "The Royal Dictionary", nimetades hea tava kohaselt ka kasutatud allikaid. Millegipärast “unustas" ta mainida G. Miège'i, kelle sõnaraamatust, nagu hiljem selgus, võeti kas otse või väikeste muudatustega üle umbes 70\% märksõnadest koos vastetega (Cormier 2005).

Ka Eestis pole sõnaraamatuplagiaadi kahtlus tundmatu asi. Arnold Kask (1955) on 18. sajandi sõnaraamatutest ülevaadet tehes leidnud, et nii Anton Thor Helle kui ka August Wilhelm Hupel on kasutanud suurel määral Salomo Heinrich Vestringi (umbes 1720-ndad) sõnaraamatu ainestikku, sealhulgas A. T. Helle (1732) käsiraamatus avaldatud sõnastik "toetub täiel määral" S. H. Vestringi käsikirjalisele sõnaraamatule (Kask 1955: 190). Käsiraamatu eessõnas on märgitud, et materjal on kogutud "ühe kristliku sõbra" ja läbi töötatud A. T. Helle poolt. "Kristliku sõbra" üle on arutlenud ka Arvo Krikmann (1986) ja Kristiina Ross (EEVA). A. Krikmanni arvates kinnitab A. Kase arvamust kõige tugevamini S. H. Vestringi alfabeet, mis on järjestatud väga veidral viisil ning mida sellisena kordab ka A. T. Helle "Anweisung” (Krikmann 1986: 84). K. Ross ei pea samuti A. T. Helle sõnastikku originaalmaterjaliks, sest see "tugineb S. H. Vestringi (märksa mahukamale) käsikirjalisele sõnastikule", ent kuna kohati on seal S. H. Vestringistki rikkalikumat materjali, siis "on oletatud, et Thor Helle kas lisas neile oma kogutud materjali või kasutas lisaks Vestringi käsikirjale veel kellegi materjale.” (EEVA)

Järgnevas kirjeldatakse 21. sajandi algul Eestis läbi viidud leksikograafiaekspertiisi käiku. Alustatakse kohtuasjast ja autoriõiguse vastavatest kirjakohtadest, kirjeldatakse ekspertiisi lähteandmeid (sõnaraamatuid), ülesandeid ja Eesti Keele Instituudis välja töötatud meetodit. Seejärel analüüsitakse vaidlusalust materjali ette antud ekspertiisiülesannete kaupa. Lõpuks antakse ülevaade ekspertiisitulemuste rakendamisest Eesti õigussüsteemis, käsitletakse plagiaadi piiritlemise probleemi ja pakutakse välja piirmäär kakskeelsete sõnaraamatute originaalsuse üle otsustamiseks.

\section{Kohtuasi: sõnaraamatuvarguse süüdistus}

200o. aastal kaebas kirjastus TEA kohtusse firma Festart, süüdistades viimast sõnaraamatuvarguses. Juhtumit menetleti kriminaalasjana seitse aastat, kuni 2007. aasta kevadeni. Festarti ja selle juhti Sergei Gluhhovit süüdistati selles, et nad aastatel 1999-2004 andsid CD-ROM-il välja inglise-eesti sõnaraamatu versioone, kasutades nende koostamisel TEA sõnaraamatute elektroonilisi põhjasid, omamata selleks kirjastuse luba. Vaidlustatud sõnaraamat pretendeerib originaalteose nimetusele, sest ei pakendil ega lisatekstides leidu ühtki viidet kasutatud allikatele. Muul juhtumil oleks tulnud ära näidata algse teose autori nimi, teose pealkiri (nimetus) ja allikas, kus teos on avaldatud, nagu sätestab autoriõiguse seadus (AÕS $\S 35 \lg 3$ ). Kohtuasja lahendamiseks sai Eesti Keele Instituut 2002. aastal Tallinna Politseiprefektuuri kriminaalosakonna majanduskuritegude talituselt ülesande läbi viia leksikograafiaekspertiis. ${ }^{1}$

Olgu vahemärkusena öeldud, et kuni 2007. aasta lõpuni töötas Eestis kaks riiklikku ekspertiisiasutust, ${ }^{2}$ mis aga kumbki nii spetsiifilist ekspertiisi ei tei- 
nud. ${ }^{3}$ Lähimaks, st intellektuaalse sfääriga lõikuvaks võis ehk pidada dokumendi-, infotehnoloogia-, ka kujutise uuringut, millega eksperdid toona lähemalt tutvust ei teinud.

\subsection{Autoriõigusest}

Teoste hulgas, millele tekib autoriõigus, on autoriõiguse seaduses nimetatud väga mitmesuguseid teoseid: kirjalikke (ilukirjandus, publitsistika, erisugused teadustöö tulemused jms) ja suulisi teoseid (kõned, jutlused jms), muusika-, tantsu- ja kujutava kunsti teoseid, arvutiprogramme, standardeid, andmebaase jpm. Autoriõigus tekib ka tuletatud teosele, milleks on "teose tôlge, algse teose kohandus (adaptsioon), töötlus (arranžeering) ja teose muu töötlus” (AÕS § 4 lg 22). Põhiline kriteerium on, et teos oleks "autori enda intellektuaalse loomingu tulemus" (AÕS § $4 \lg 2$ ).

Ajal, mil arvutiajastu soodustab hõlpsat kopeerimist, diskuteeritakse ühtelugu autori- ja omanikuõiguse kontrolli ja vabakasutuse üle eri elualadel. ${ }^{4}$ Seaduses on sätestatud mõned intellektuaalse tegevuse tulemused, millele autoriõigus (seni) ei laiene, nagu rahvaloominguteosed, päevauudised, faktid, andmed, arvutiprogrammi elemendid jms (AÕS § 5). Sõnu sõnastik või sõnaraamat ei esine autoriõiguse seaduses kordagi.

Sõnaraamatule võiks autoriõigus tekkida kui originaalsele andmebaasile ("süstemaatiliselt või metoodiliselt korrastatud iseseisvate teoste, andmete või muu materjali kogu") või kui tuletatud teosele. Mille alusel aga eristada autoriõigusega kaitstavat (tuletatud) teost plagiaadist - selle kohta puuduvad autoriõiguses kaudsedki juhtnöörid. Kui arvutiprogramm on tervikuna kaitstud kui teos, aga selle elemendid mitte, siis kuidas on lood sõnaraamatuga? Süütuse presumptsiooni põhimõttel näeb seadus ette, et kui asja õiguskuulekuses kaheldakse, siis lasub tõendamiskohustus sellel, kes on vaidlustanud teose autoriõigusega kaitstuse (AÕS $\S 4)$, siinses kohtuasjas niisiis kirjastusel TEA.

\subsection{Ekspertiisi lähteandmed ja ülesanded}

Ekspertiisiakti ${ }^{5}$ sissejuhatavas osas on ekspertiisi lähteandmetena üles loetud kõik asjasse puutuvad sõnaraamatud, mis jagunevad kahte leeri. Ühel pool on vaidlustatud materjal ise ehk ekspertiisi objekt, milleks on kirjastuse Festart üllitatud inglise-eesti sõnaraamat CD-ROM-il ning seda toetav võrdlusmaterjal. Teisel pool on kannatanu võrdlusmaterjal (kakskeelsed inglise-eesti või eesti-inglise sõnaraamatud). Tabelis 1 on kirjas kõik kohtuasjas osalenud sõnaraamatud koos märkega nende staatuse kohta. (Edaspidi on artiklis kasutatud poolele osutavaid lühinimesid, nt FESTART-sõnaraamat, TEA teaduse ja tehnika sõnaraamat.)

3 2008. a loodud asutuse põhikirjas (Riigi Teataja 20.12.2007) on üles loetud asutuses tehtavad uuringud, nt alkoholi-, DNA-, dokumendi-, hääle-, infotehnoloogia-, jälje-, kujutise-, käekirja-, narkootilise aine jpm uuringud (kokku 30 liiki), samuti ekspertiisiliigid: 1) kohtuarstlik, 2) kohtubioloogia-, 3) kohtukeemia-, 4) kohtupsühhiaatriaja 5) kriminalistikaekspertiis.

${ }^{4}$ Vt nt Evi Arujärve (2008) kirjutist "Kultuur - missioon ja äri".

5 Ekspertiisiakt kriminaalasjas nr 00231000138 "Festart Dictionary English-Estonian. 70000 Entries. CD-ROM

Version 3.10". Käsikiri Eesti Keele Instituudis. Leksikograafiaekspertiisi peaekspert: Piret Voll. 
Tabel 1. Ekspertiisi lähteandmed (kohtuasjasse puutuvad sõnaraamatud)

\begin{tabular}{|c|c|c|c|}
\hline $\mathbf{N r}$ & Täiskirje ekspertiisiaktis & $\begin{array}{l}\text { Lühinimi siinses } \\
\text { artiklis }\end{array}$ & $\begin{array}{l}\text { Materjali } \\
\text { staatus }\end{array}$ \\
\hline 1 & $\begin{array}{l}\text { "FESTART DICTIONARY ENGLISH-ESTONIAN. } \\
70000 \text { ENTRIES. CD-ROM Version 3.10" } \\
\text { ISBN } 9985-9063-4-9^{6}\end{array}$ & FESTART-sõnaraamat & $\begin{array}{l}\text { vaidlustatud } \\
\text { materjal }\end{array}$ \\
\hline 2 & $\begin{array}{l}\text { English-Latvian Dictionary / Anglu-latviešu vārdnīca. } \\
\text { 3rd improved edition. Rīga: Jāna Sēta Publishers \& Prin- } \\
\text { ters Ltd, 1997. } 1328 \text { lk }\end{array}$ & FESTART inglise-läti & $\begin{array}{l}\text { võrdlus- } \\
\text { materjal }\end{array}$ \\
\hline 3 & $\begin{array}{l}\text { Teaduse ja tehnika seletav sõnaraamat I-II. } \\
\text { Tallinn: TEA Kirjastus, 1997. } 1667 \text { Ik }\end{array}$ & $\begin{array}{l}\text { TEA teadus ja teh- } \\
\text { nika }\end{array}$ & $\begin{array}{l}\text { võrdlus- } \\
\text { materjal }\end{array}$ \\
\hline 4 & $\begin{array}{l}\text { Teaduse ja tehnika seletav sõnaraamat. Eesti-inglise. } \\
\text { Lisaköide. Tallinn: TEA Kirjastus, 1998. } 544 \mathrm{lk}\end{array}$ & $\begin{array}{l}\text { TEA teadus ja tehni- } \\
\text { ka lisaköide }\end{array}$ & $\begin{array}{l}\text { võrdlus- } \\
\text { materjal }\end{array}$ \\
\hline 5 & $\begin{array}{l}\text { PASSWORD. Inglise-eesti seletav sõnaraamat. } \\
\text { Tallinn: TEA Kirjastus, 1995. } 856 \mathrm{lk}\end{array}$ & TEA Password & $\begin{array}{l}\text { võrdlus- } \\
\text { materjal }\end{array}$ \\
\hline 6 & $\begin{array}{l}\text { Eesti-inglise majandussõnastik. 2. trükk. } \\
\text { Tallinn: TEA, 1998. } 496 \mathrm{lk}\end{array}$ & $\begin{array}{l}\text { TEA eesti-inglise } \\
\text { majandus }\end{array}$ & $\begin{array}{l}\text { võrdlus- } \\
\text { materjal }\end{array}$ \\
\hline 7 & $\begin{array}{l}\text { Inglise-eesti majandussõnaraamat. } \\
\text { Tallinn: Keelefirma TEA, 1995. } 496 \mathrm{lk}\end{array}$ & $\begin{array}{l}\text { TEA inglise-eesti } \\
\text { majandus }\end{array}$ & $\begin{array}{l}\text { võrdlus- } \\
\text { materjal }\end{array}$ \\
\hline 8 & $\begin{array}{l}\text { Inglise-eesti ja eesti-inglise ärisõnastik. } \\
\text { Tallinn: Keelefirma TEA, 1993. } 560 \text { lk }\end{array}$ & TEA inglise-eesti äri & $\begin{array}{l}\text { võrdlus- } \\
\text { materjal }\end{array}$ \\
\hline 9 & $\begin{array}{l}\text { Festart; English-Estonian Dictionary of Economics } \\
2.47 \text { [elektrooniline teavik] }\end{array}$ & $\begin{array}{l}\text { FESTART inglise-eesti } \\
\text { majandus }\end{array}$ & $\begin{array}{l}\text { täiendav } \\
\text { võrdlus- } \\
\text { materjal }\end{array}$ \\
\hline 10 & $\begin{array}{l}\text { Silvet, Johannes 1989. Inglise-eesti sõnaraamat I-II. } \\
\text { Kolmas, parandatud ja täiendatud trükk. } \\
\text { Tallinn: Valgus }\end{array}$ & Silvet 1989 & $\begin{array}{l}\text { täiendav } \\
\text { võrdlus- } \\
\text { materjal }\end{array}$ \\
\hline 11 & $\begin{array}{l}\text { Inglise-eesti sõnastik. Eesti Keele Instituudi vabavara } \\
\text { Internetis }^{7}\end{array}$ & EKI sõnastik & $\begin{array}{l}\text { täiendav } \\
\text { võrdlus- } \\
\text { materjal }\end{array}$ \\
\hline 12 & Festart. Keyword, English-Estonian Dictionary 2.44 & FESTART Keyword & $\begin{array}{l}\text { täiendav } \\
\text { võrdlus- } \\
\text { materjal }\end{array}$ \\
\hline
\end{tabular}

Ekspertiisimääruses oli sõnastatud neli ülesannet (küsimust), millele ekspertiis pidi vastama.

1. Missugused tunnused viitavad võrdlusmaterjalina esitatud sõnastike ja/ või nende elektrooniliste põhjade kasutamisele FESTART-sõnaraamatu koostamisel?

2. Kui palju on vaidlustatud materjalil (FESTART-sõnaraamatul) märksõnu või muid tunnuseid, mis kattuvad võrdlusmaterjalina esitatud sõnastike märksõnade või muude tunnustega?

3. Kuidas võis võrdlusmaterjalina esitatud sõnastike ja/või nende elektrooniliste põhjade alusel tehniliselt toimuda FESTART-sõnaraamatu märksõnade, vastete ja indeksite moodustamine?

706 Täpne märksõnade arv on 71154.

7 Vt www.eki.ee/dict/inglise/ (20.11.2007). 
4. Kas FESTART-sõnaraamat on originaalteos või on see tuletatud teos, mis ulatuses see teos kattub võrdlusmaterjalina esitatud teostega?

Järgnevas on neid küsimusi ühekaupa analüüsitud. Aga enne seda meetodist.

\section{Meetod}

Nagu juba eespool mainitud, ei olnud leksikograafiaekspertiisi tegemiseks otsest eeskuju leida. Peale selle tuli Tallinna Politseiprefektuuri kriminaalosakonna ettekirjutusena ekspertiis läbi viia absoluutses ulatuses, st toetumist statistilisele valimile nad ei aktsepteerinud. Seega oli mõistlik, nagu ka nüüdisajale kohane, kasutada keeletehnoloogia abi, seda enam, et kogu materjal - nii vaidlustatud teos kui ka võrdlusmaterjal - loovutati ekspertide käsutusse elektroonilisel kujul.

Ekspertiisianalüüsi peamine meetod oli sõnaraamatute elektrooniliste versioonide läbiv võrdlus arvutiprogrammide abil. Aga küsimus oli: mida, millist üksust mõõta? Kui element üksi on liiga vähe, et sellele toetuda, siis elementide kombinatsioon võiks teataval määral peegeldada autori loomingut. Kakskeelses sõnaraamatus võiks vähimaks oluliste infoüksuste kombinatsiooniks pidada märksõna koos oma vaste(te)ga: ei saa olla kakskeelset sõnaraamatut, kus märksõnade juures pole tõlkevasteid (viiteartiklis asendab vastet viide) - need üksused on obligatoorsed igas tõlkesõnaraamatus. Vasteüksus võib koosneda ühest vastest (ühest sõnast või mitmesõnalisest väljendist, vt näide 1a). Sagedamini on antud mitu vastet, mis omavahel on eraldatud komaga (1b). Ei ole kuigi tavaline, et märksõnal ongi ainult üks vaste, eriti üldkeele sõnaraamatus, sest pole kaht keelt, mis üks-ühele kattuks. ${ }^{8}$ Väga tavaline on vastete loendis ka semikoolon, mis harilikult eraldab tähenduselt veidi kaugemaid vasteid $(1 \mathrm{~b}, 2)$.

(1a) post-paid .. saatekuludeta [FESTART-sõnaraamat] w pikkusühiku koormuse sümbol [FESTART-sõnaraamat]

(1b) voidable .. annulleeritav, tühistatav; vaidlustatav [FESTART-sõnaraamat]

(2) micro- väike, miljondik-; pisi-; miljondik, o,000ooo1 m [FESTARTsõnaraamat]

Eksperdid määratlesid analüüsi põhiüksuseks märksõna koos oma vaste(te)ga, lähtudes vasteloendis esinevast semikoolonist. Koma eraldab lähemaid vasteid ühekaupa ega sobi seega nii hästi rühma eraldajaks (märksõna-vaste-grupis oleks alati ainult üks vaste). Peale selle võib koma esineda vaste osana pikemates väljendites, murdarvudes jm (vt näide 2). Seega eraldab võrreldava märksõna-vaste-grupi (edaspidi MV-grupp) alati semikoolon, kusjuures märksõna korratakse iga grupi juures (vt tabel 2).

FESTART-sõnaraamatus, mis sisaldab 71154 märksõna, on kokku 122915 niisugust MV-gruppi. Ühe või teise TEA sõnastiku osakaalu FESTART-sõnaraamatus on iseloomustatud protsentides MV-gruppide kaupa. Välja toodud erinevuste või sarnasuste rõhutamiseks on (ekspertiisis esitatud) näidetes vastavad kohad alla joonitud, tabelitesse on lisatud selgituste tulp.

${ }^{8}$ Spetsiaalses, nn kakskeelestatud sõnaraamatus võib olla põhimõte esitada ainult üks vaste (seda tüüpi sõnaraamat on näiteks TEA Password), aga sealgi "segab mängu" leksikaalne mitmetähenduslikkus: üks vaste vahendab üht tähendust. 
Tabel 2. Märksõna-vaste-gruppide (MV-grupid) näiteid

\begin{tabular}{|l|l|l|}
\hline Sõnaartikkel & MV-grupid & Selgitus \\
\hline $\begin{array}{l}\text { micro- väike, miljondik-; } \\
\text { pisi-; miljondik, }\end{array}$ & $\begin{array}{l}\text { kokku 3 MV-gruppi: } \\
0,0000001 \mathrm{~m}\end{array}$ & $\begin{array}{l}\text { 1) } \text { micro- väike, miljondik-; } 3 . \mathrm{MV} \text {-grupis on kaks } \\
\text { vastet (eraldatud komaga), } \\
\text { 2) micro- pisi-; } \\
\text { 3) micro- miljondik, 0,0000001 m }\end{array}$ \\
\hline $\begin{array}{l}\text { realise [verb] aru saama; } \\
\text { täide viima; realiseerima }\end{array}$ & $\begin{array}{l}\text { kokku 3 MV-gruppi: } \\
\text { 1) realise aru saama; } \\
\text { 2) realise täide viima; } \\
\text { 3) realise realiseerima }\end{array}$ & $\begin{array}{l}\text { kõik grupid koosnevad ühest } \\
\text { (mitmesõnalisest) vastest }\end{array}$ \\
\hline
\end{tabular}

\section{Esimene ülesanne: reetlikud tunnused}

Tunnusena, mis võiks viidata sõnaraamatu ja/või nende elektrooniliste põhjade kasutamisele teise sõnaraamatu koostamisel, on ekspertiisis välja toodud järgmised elemendid ja/või seosed: a) korduvad märksõnad, b) märksõnavaliku kattuvus, c) MV-gruppide kattuvus, d) trükivead (õigekirjavead, küljenduselementide jäänused), e) haruldased vasted. Muud tehnilised detailid (nt muutunud tähestikjärjestus, lihtsustatud diakriitikutega tähed, eesti-inglise pöördindeks) on sõnastikuprogrammi eripärad ja siduvat informatsiooni ei kanna.

Märksõnavaliku või muude tunnuste kattuvust (seosed b ja c) on kirjeldatud järgmises, teist ülesannet käsitlevas 6. osas. Siin on lähemalt vaadeldud ülejäänuid reetlikke tunnuseid.

\subsection{Korduvad märksõnad}

FESTART-sõnaraamatu 71154 märksõnast ${ }^{9}$ on korduvaid märksõnu 4585 (6,4\%), st ligi 5000 juhtumil väljastatakse päringu tegemisel vastuseks mitu sama märksõnaga artiklit. See tõsiasi ei külvaks kahtlust, kui tegemist oleks seda märksõna sisaldavate väljenditega, mitte mitme identse märksõnaga. Näiteks "Eesti keele seletussõnaraamatus" tehtud märksõnapäring must toob vastuseks nii lihtsõnast märksõna enda (must) kui ka seda osist sisaldavad liitsõnad (kärbsemust, mustjuur, mustsada, trükimust jt) ja väljendid (must lammas, must valgel, ei musta ega valget jt). Sõnavarabaaside üks põhinõudeid on märgistada kirjeldusobjekt unikaalseks. Seega kui märksõna on kujult sama (nt homonüüm), on tal ikkagi üldjuhul mingi eristav tähis juures.

FESTART-sõnaraamatus on asi teisiti: lõviosa (u 90\%) mainitud 4585-st artiklist on sellised, kus märksõna kordub muutumatul kujul. Väljastatud n-ö teise artikli vastena esineb siis enamasti majandustermin (vt tabel 3 ). See viib vägisi mõtted elektroonilisele kopeerimisele (majandussõnastikust?), kuivõrd tavalisel moel koostatud sõnaraamatus on sellised juhtumid enamasti ühe märksõna all, kas siis eri tähendusena (eraldatud tähendusnumbriga) või tähendusrühmana (semikooloniga). 
Tabel 3. Korduvate märksõnadega artikleid FESTART-sõnaraamatus

\begin{tabular}{|l|l|l|}
\hline Otsisõna & Väljastatav vastus & Selgitus \\
\hline post-paid & $\begin{array}{l}\text { post-paid [adjective] saate- } \\
\text { kuludeta } \\
\text { post-paid [economics] } \\
\text { postikulud tasutud, saateku- } \\
\text { ludeta, franko }\end{array}$ & $\begin{array}{l}\text { märksõna kordub muutumatul kujul, kusjuures } \\
\text { teise märksõna järel esineb majandustermini mär- } \\
\text { gend economics }\end{array}$ \\
\hline yuppie & $\begin{array}{l}\text { yuppie .. [noun] jappi } \\
\text { yuppie, yuppy [econo- } \\
\text { mics] juppi, jappi }\end{array}$ & $\begin{array}{l}\text { väljastatakse kaks väga sarnast (inimese poolt } \\
\text { toimetamata?) sõnaartiklit; } \\
\text { märksõna kordub muutumatul kujul, kusjuures } \\
\text { teise märksõna järel esineb majandustermini mär- } \\
\text { gend economics }\end{array}$ \\
\hline
\end{tabular}

Ülejäänud juhtudel (10\%) esineb korduv osis fraasi osana, mis on ka pabersõnastikes tavaline, kuigi seal on sellised juhtumid enamasti kasutusnäite või allmärksõna positsioonis (3), samas kui FESTART-sõnaraamatus on need tõstetud märksõna staatusse (4). Paljudes pabersõnastikes kuulub sõnaartiklisse märksõna tuletisi, mitmesõnalisi püsiühendeid ja väljendeid, samas kui arvutisõnastikes paigutatakse need kõik tavaliselt eraldi (st märksõna positsiooni). Kõrvalekaldena on siin paslik juhtida tähelepanu märksõnade arvule: sel moel eraldi esitatud märksõnad paisutavad sõnaraamatu mahtu, mida on muidugi soodus kasutada (arvuti)toodet reklaamides. Tegelikult võiks FESTART-sõnaraamatu "suurt" mahtu (70 ooo märksõna) pidada võrdväärseks umbes keskmise suurusega (st 40-50 ooo märksõnaga) pabersõnaraamatuga.

(3) voidable [economics] annulleeritav, tühistatav; vaidlustatav • voidable act vaieldav toiming; voidable title vaieldav omandiõigus [võimalik artikkel pabersõnaraamatus]

(4a) voidable [economics] annulleeritav, tühistatav; vaidlustatav [FESTARTsõnaraamat]

(4b) voidable act [economics] vaieldav toiming [FESTART-sõnaraamat]

(4c) voidable title [economics] vaieldav omandiõigus [FESTART-sõnaraamat]

\subsection{Trükivead: õigekirja- ja poolitusvead, küljenduselementide jäänused}

Leksikograafias (nagu muudeski kirjalikes tekstides) on samade trükivigade esinemine üks kindlamaid tõendeid selle kohta, et üks teos kopeerib teist: ilmselget viga ei ole lihtsalt võimalik teistmoodi paljundada, kui maha kirjutades: kas siis täiesti asjatundmatu inimesena või, mis veelgi hõlpsam, elektrooniliselt, kõike mehaaniliselt üle võttes. Ekspertiisis on välja toodud nii korduvaid õigekirja- ja poolitusvigu (vt tabel 4) kui ka küljenduselementide jäänuseid (vt näide 5). Näiteks 69-st ekspertiisi käigus leitud TEA Passwordi poolitusveast kordub 68 (98,5\%) FESTART-sõnaraamatus. 
Tabel 4. Kattuvad trükivead: õigekirja- ja poolitusvead

\begin{tabular}{|l|l|l|}
\hline TEA inglise-eesti majandus & FESTART-sõnaraamat & Selgitus \\
\hline BOOM buum, kõrgkonjuktuur; .. & $\begin{array}{l}\text { boom [economics] buum, kõrgkon- } \\
\text { juktuur; .. }\end{array}$ & $\begin{array}{l}\text { Õigekirjaviga: p.o } \\
\text { kõrgkonjunktuur }\end{array}$ \\
\hline quantitatve CHANGE & $\begin{array}{l}\text { quantitatve change [economics] } \\
\text {.. }\end{array}$ & $\begin{array}{l}\text { Õigekirjaviga: } \\
\text { p.o quantitative } \\
\text { change }\end{array}$ \\
\hline $\begin{array}{l}\text { SECOND bill of (exchange) } \\
\text { sekundaveksel, .. }\end{array}$ & $\begin{array}{l}\text { second bill of [economics] } \\
\text { sekundaveksel }\end{array}$ & $\begin{array}{l}\text { viga märksõnas: } \\
\text { programmiga on } \\
\text { välja jäetud kõik } \\
\text { sulgudes osad }\end{array}$ \\
\hline $\begin{array}{l}\text { courtly [adjective] ... } \\
\text { - peene-kombeline }\end{array}$ & $\begin{array}{l}\text { courtly [adjective] õukondlik; } \\
\text { peene-kombeline }\end{array}$ & poolitusviga \\
\hline
\end{tabular}

Küljendusvead on reeglina tekkinud uue materjali lisamisel ja/või millegi ümbertõstmisel - see seletab ülearuseid tühikuid (5a), topelt-kirjavahemärke (5b), rea lõppu "unustatud" kirjavahemärke (5c) ja muid kirjavahemärkidega seonduvaid vigu (5d) (kõik näited FESTART-sõnaraamatust).

(5a) carriage free [economics] franko, tasuta

(5b) letter of credit [economics] akreditiiv, krediitkiri, rambuur,; maksekäsund

(5c) compensate [economics] korvama, hüvitama, tasuma; tasakaalustama, balansseerima,

(5d) appreciate [economics] hindama; arvesse võtma; hinnas tõusma, hinda tõstma,väärtuses kasvama

Samalaadsele tehnilisele argumendile - veidrale tähestikjärjestusele - on osutatud juba 18. sajandil Helle-Vestringi sõnaraamatukriitikas, millest oli juttu siinse artikli sissejuhatuses.

\subsection{Haruldased vasted}

Kui suure kasutussagedusega sõnade vastete kattumine on mõnevõrra ootuspärane,$^{10}$ siis haruldaste märksõnade ja kummaliste vastete kordumine mitmes sõnaraamatus seda kindlasti ei ole. Probleem on muidugi, kuidas kõik need haruldased vasted üles leida. Kuna see toona ei olnud keeletehnoloogiliselt lahendatav (põhimõtteliselt saaks mõõta iga eesti sõna sagedust tekstikorpuses - aga põhjendatud tulemuse saamiseks läheks vaja vähemalt 100 mln sõne suurust üldkeele korpust, mida Eestis pole veel praeguseni olemas), siis tõid eksperdid n-ö käsitsi välja TEA sõnaraamatutes silma hakanud mitmes mõttes erilisi vasteid.

Leksikograafile arusaamatul põhjusel korduvad need FESTART-sõnaraamatus, kuna tavaliselt selliseid asju uustrüki jaoks täiendatakse või parandatakse. Kui TEA teaduse ja tehnika sõnaraamatus, mille inglise aluspõhja (Chambers Ltd) on viimati uuendatud 1988. a, on esitatud (vananenud) märksõna ja vaste (6a), siis 
sama kordub FESTART-sõnaraamatus (6b), kus toimetajad ei ole kiiresti vananevaid infoteaduse jm termineid uuemate vastu välja vahetanud. Kui TEA teaduse ja tehnika sõnaraamatus on ära toodud spetsiifilisi termineid, mis üldkeele või väiksemates erialasõnastikes puuduvad (7a, 8a), siis on need olemas ka FESTARTsõnaraamatus (7b, 8b). Näidete 7 ja 8 puhul võib tähelepanu juhtida ka identses sõnastuses vastetele. Ebaharilik on ka allpool toodud vaste tähtpäevuma (10b). Võrdluseks: ekspertide kogemus sõnaraamatute koostamisel kinnitab, et isegi juhul, kui märksõna tähendusele on lubatud panna ainult üks vaste, esitavad eri tegijad selle vaste pisut isemoodi.

(6a) XNS [Comp] Abbreviation for Xerox network system. .. • XNS [TEA teaduse ja tehnika]

(6b) XNS [computers] XNS [FESTART-sõnaraamat]

(7a) VOS [Image Tech] Abbreviation for video on sound. See background video. $\bullet$ helipealne video, taustvideo [TEA teaduse ja tehnika]

(7b) VOS [photography] helipealne video, taustvideo [FESTART-sõnaraamat]

(8a) taungya $[\mathrm{Ecol}] . . \cdot$ agrometsanduse vorm troopilistel aladel $\quad$ [TEA teaduse ja tehnika]

(8b) taungya agrometsanduse vorm troopilistel aladel [FESTART-sõnaraamat]

\section{Teine ülesanne: kattuvate märksõnade või muude tunnuste määr}

FESTART-sõnaraamatu materjali võrreldi ekspertiisis sisuliste alarühmade, valdkondade ja vastavate sõnaraamatute kaupa: 1) majandusterminid (võrdlusaluseks TEA inglise-eesti majandus), 2) tehnikaterminid (TEA teadus ja tehnika) ja 3) üldsõnavara (TEA Password ja Silvet 1989). Pärast iga alarühma analüüsimist eemaldati vastav osa (MV-grupid) algsest FESTART-sõnaraamatust. Iga järgnevat alarühma analüüsiti eelmise osa võrra vähendatud algmaterjalis.

\subsection{Majandusterminid}

Majandussõnavara osatähtsus on FESTART-sõnaraamatus (70 000 märksõna, 122915 MV-gruppi) märkimisväärselt suurem kui muudes kakskeelsetes üldkeele sõnastikes: majandussõnad (märgendiga [economics] 'majandus') moodustavad FESTART-sõnaraamatu kogumahust ligi 40\% (kokku 27387 märksõna).

Majandusterminite osa eristub muudest sõnavarakihtidest mitme iseärasuse poolest: märksõnadel puudub hääldus (9-10); kogu FESTART-sõnaraamatus esinevad ainult selles rühmas mitmest sõnast koosnevad märksõnad (10); esineb trükivigu: veatüübid nagu "tühik koma ees" (9a), "koma järel puudub tühik" (9c), "kirjavahemärk rea lõpus" (9b) või "kaks kirjavahemärki üksteise järel” (10a) on selles rühmas ülekaalukas enamuses. 
(9a) billion [economics] biljon, miljard

(9b) bunco, bunko [economics] pettus,

(9c) discuss [economics] arvamusi vahetama, diskuteerima,polemiseerima, väitlema, vaidlema, arutama, arutlema

(10a)letter of credit [economics] akreditiiv, krediitkiri, rambuur,; maksekäsund

(10b)become due [economics] saabuma, tähtpäevuma, aeguma; maksmisele kuuluma

Majandustermineid analüüsiti kahes etapis: esmalt võrreldi FESTART-sõnaraamatut teise sama kirjastuse sõnaraamatuga (FESTART inglise-eesti majandus, 27 500 märksõna), seejärel kontrolliti viimase võimalikku seotust TEA inglise-eesti majandussõnaraamatuga.

Kahe Festardi sõnaraamatu vigaste kohtade võrdlemisel ilmnes mitu asja. Esiteks, MV-gruppide kokkulangevus on sama hea kui täielik: võib väita, et FESTART-sõnaraamatu 27891 MV-gruppi (23\%) pärinevad sama kirjastuse majandussõnaraamatust (mis samuti pole originaalne, aga sellest allpool). Ülevõtmisel on automaatselt välja jäetud sulgudes olnud kommentaarid, täpsustused, keeleviited jms, seejärel tehtud korrektuur ja lisatud ka mõningaid uusi märksõnu. Tõenäoliselt on märgend [economics] lisatud lõpuks programmi abil ja ilma järgneva korrektuuri või toimetamiseta. Seda illustreerib märksõna yeepy, kus märgendi õige koht peaks olema eesti vaste aktiivsed vanurid ees, mitte ingliskeelse tähenduse seletuse keskel (11).

(11) yeepy, youthful [economics] energetic elderly people involved in everything aktiivsed vanurid [FESTART]

Teiseks tulevad esile tüüpiliste vigade tekkekohad, st kohad, kus midagi on muudetud, kas uue materjali elektroonilisel lisamisel, väljajätu kohal, sulgudes esitatud materjali ärajätmisel, küljenduse poolitusvihjete puhul jne (vt tabel 5).

Tabel 5. Festardi sõnaraamatute võrdlus: tüüpilisi veakohti

\begin{tabular}{|l|l|l|}
\hline $\begin{array}{l}\text { FESTART inglise-eesti } \\
\text { majandus }\end{array}$ & FESTART-sõnaraamat & Vea tekke selgitus \\
\hline $\begin{array}{l}\text { APPRECIATE hindama; tänulik } \\
\text { olema; arvesse võtma; hinnas } \\
\text { tõusma, hinda tõstma }\end{array}$ & $\begin{array}{l}\text { appreciate [economics] hindama; } \\
\text { arvesse võtma; hinnas tõusma, hinda } \\
\text { tõstma, väärtuses kasvama }\end{array}$ & $\begin{array}{l}\text { vahele lisatud vaste } \\
\text { ees }\end{array}$ \\
\hline $\begin{array}{l}\text { IRRETRIEVABLE korvamatu; } \\
\text { lootusetu; tagasisaadamatu; } \\
\text { taastamatu; heastamatu }\end{array}$ & $\begin{array}{l}\text { irretrievable [economics] } \\
\text { korvamatu, heastamatu; lootusetu; } \\
\text { tagasisaadamatu; taastamatu }\end{array}$ & $\begin{array}{l}\text { vahele lisatud vaste } \\
\text { ees }\end{array}$ \\
\hline $\begin{array}{l}\text { REALITY reaalsus, tegelikkus } \\
\text { reality [economics] tegelikkus, } \\
\text { reaalsus, }\end{array}$ & kohavahetuse kohal \\
\hline $\begin{array}{l}\text { BILLION biljon (UK, Saksamaa), } \\
\text { miljard (USA, Prantsusmaa) }\end{array}$ & billion [economics] biljon, miljard & $\begin{array}{l}\text { sulgudes teksti välja- } \\
\text { jätu kohal }\end{array}$ \\
\hline GROSS .. sum-maarne & gross [economics] .. sum-maarne .. & poolitusvihje kohal \\
\hline
\end{tabular}


Kolmandaks, kõigile FESTART inglise-eesti majanduse sõnaraamatust pärit märksõnadele on lisatud FESTART-sõnaraamatus erialamärgend [economics] (vt tabel 5, 2. veerg). Nii on tekkinud FESTART-sõnaraamatusse hulk "imelikke" artikleid, kus märksõnad korduvad (sellest oli ka eespool juttu), kusjuures ka erialamärgend on esitatud mõlemas artiklis (12a, 12b): sest kuskilt võetuna on materjalis juba olemas hääldusega ja märgendiga varustatud artikkel. Leidub artikleid, kus majanduse osa (nagu ka teised erialaterminid) on sattunud suisa üldsõnavaraosa keskele (13).

(12a) account [ö’kaunt] [verb] lugema, arvama; punkte saavutama; tapma; [noun] arvestus; [economics] arve; seletus; jutustus [FESTART-sõnaraamat]

(12b)account [economics] raamatupidamiskonto; konteerima, kirjendama; finantsaruanne; register; alaline klient; riigieelarve täitmise aruanne; börsitehingu arvutlus; tasumata võlakohustus; aru/selgitusi andma; aruandlus, äriraaamatud; vastutama, vastutust kandma [FESTARTsõnaraamat]

(13) principal ['prinsipl] [adjective] peamine; [noun] printsipaal; tööandja; direktor; [jurisprudence] peasüüdlane; [building] peatala; [economics] kapital; esinäitleja, esilaulja [FESTART-sõnaraamat]

Ekspertiisi käigus selgus, et FESTART inglise-eesti majandussõnaraamatus on võrdluses TEA inglise-eesti majandussõnaraamatuga omakorda täpseid MV-gruppide vastavusi 26698 (97\%). Elektroonilise küljenduspõhja kasutamisest annavad taas tunnistust poolitusvihjete täpne kordamine, kokkulangevad õigekirjavead jm. Näiteks leidub äärmiselt reetlik kirjaviga vastes äriraaamatud, mis pärineb juba TEA inglise-eesti majanduse pabersõnastikust, esinedes nõnda igas kolmes allikas: esimesena TEA-s, seejärel kahes Festardi sõnaraamatus.

\subsection{Tehnikaterminid}

Pärast majandussõnavara (27 387 märksõna koos oma MV-gruppidega) eraldamist on vaadeldud allesjäänud osa (42 613 märksõna), milles omakorda eristub suur rühm - märksõnad ilma häälduseta, erialamärgenditega [zoology], [chemistry], [physics], [building], [geology] jne. Selliste erialamärgenditega sõnu oletasid eksperdid pärinevat TEA teaduse ja tehnika sõnaraamatust. Ilma häl̈lduseta märksõnu, mis pole majandusterminid, on kogu FESTART-sõnaraamatus 25\% (kokku 18024 märksõna). Ühelt poolt kuuluvad siia hulka märksõnad, mille puhul sõnastikes hääldust sageli ei esitatagi (akronüümid, keemilised elemendid jms) ja märksõnad ilma igasuguse erialamärgendita. Teiselt poolt kattub osa erialatermineist tavakasutuses olevate sõnadega - siis on üldjuhul ka hääldus olemas (tõenäoliselt üle võetud TEA Passwordist, sellest on juttu allpool). TEA teaduse ja tehnika sõnaraamatuga toimiti tõenäoliselt järgneval viisil.

TEA sõnaraamatu elektrooniline versioon koosnes küljendusprogrammi Ventura failidest, millest mittevajaliku info ja kujunduselementide kustutamine võtab kogenud programmeerijal aega vaid mõne tunni (ekspertidel oli kasutada oma programmeerija, kes selle läbi proovis). Mittevajaliku info hulka kuulusid näiteks 
ingliskeelsed seletused ja tähendusnumbrid. Sel viisil "puhastatud" sõnastikku jäid vaid inglise märksõnad, erialamärgendid ja eesti vasted, kokku 51692 märksõna. Materjali võrdlus näitab, et sellest on otse üle võetud ligi $40 \%$ seal leiduvatest märksõnadest (kokku üle 20 ooo). Kogu FESTART-sõnaraamatust moodustab TEA teaduse ja tehnika sõnaraamatust pärit osa $16 \%$. Ülevõtmine on võinud toimuda järgmiste üldreeglite alusel:

1) välja on jäetud mitmesõnalised inglise märksõnad (st märksõnad, mis sisaldavad tühikut);

2) kustutatud on kõik, mis oli sulgudes (meetod on tuttav juba varasemast, nii tekib näiteks vastete kordumine);

3) teisenduse käigus on kaotsi läinud kursiiv, fondivahetus jm, mis põhjustab sisulisi vigu: vääraid märksõnu ja seletusi; palju jälgi on endast maha jätnud numbrite töötl(emat)us;

4) kaotatud on tähendusliigendus: kustutatud on tähendusnumbrid, semikoolon on asendatud komaga;

5) mitmest erialamärgendist on alles jäetud ainult esimene;

6) erialamärgendid on asendatud (osalt välja kirjutatud, osalt muudetud) (vt tabel 6).

Kõik loetletud asjaolud kinnitavad arvutiprogrammi, mitte inimesest koostaja kasutamist.

Tabel 6. Võrdlus TEA teaduse ja tehnika sõnaraamatuga: tüüpilisi veakohti

\begin{tabular}{|c|c|c|}
\hline TEA teadus ja tehnika & FESTART-sõnaraamat & Selgitus \\
\hline $\begin{array}{l}\text { ageing }[\text { Eng] .. •... 2. vananemi- } \\
\text { ne (plastide korral); } 3 \text {. vananemine } \\
\text { (ferromagneetikute korral) }\end{array}$ & $\begin{array}{l}\text { ageing [physics] vananemine, } \\
\underline{\text { vanandamine .. }} \\
\text { [physics] vananemine; vanandami- } \\
\underline{\text { ne, vanandus }}\end{array}$ & $\begin{array}{l}\text { kustutatud on sulgu- } \\
\text { des osa: tulemuseks } \\
\text { korduv erialamärgend, } \\
\text { korduvad vasted }\end{array}$ \\
\hline a-particle & a-particle & $\begin{array}{l}\text { teisenduse käigus on } \\
\text { kaotsi läinud erisüm- } \\
\text { bolid: väär märksõna }\end{array}$ \\
\hline $\begin{array}{l}\text { sthene jõu ühik meeter-tonn- } \\
\text { sekund-süsteemis, ekvivalentne } \\
\underline{10^{3}} \mathrm{~N} \text {-ga }\end{array}$ & $\begin{array}{l}\text { sthene jöu ühik meeter-tonn- } \\
\text { sekund-süsteemis, ekvivalentne } \\
\underline{103} \mathrm{~N} \text {-ga }\end{array}$ & $\begin{array}{l}\text { teisenduse käigus on } \\
\text { kaotsi läinud ülaindek- } \\
\text { sid: väär seletus }\end{array}$ \\
\hline $\begin{array}{l}\text { albedo 1. albeedo, peegeldus- } \\
\text { võime; } \underline{\mathbf{2}} \text { neutronite peegeldumi- } \\
\text { se võime pinnalt }\end{array}$ & $\begin{array}{l}\text { albedo [physics] albeedo, peegel- } \\
\text { dusvõime, neutronite peegeldumi- } \\
\text { se võime pinnalt }\end{array}$ & $\begin{array}{l}\text { kaotatud on tähen- } \\
\text { dusliigendus, semi- } \\
\text { koolon on asendatud } \\
\text { komaga }\end{array}$ \\
\hline mucilaginous $[$ Bot, Zool] lima- & mucilaginous [botany] lima- & $\begin{array}{l}\text { mitmest erialamär- } \\
\text { gendist on alles jäetud } \\
\text { ainult esimene }\end{array}$ \\
\hline $\begin{array}{l}\text { [Aero] } \\
{[\text { Bot] }} \\
{[\text { Behav] }} \\
\text { [ImageTech] } \\
\text { [Space] }\end{array}$ & $\begin{array}{l}\text { [aviation] } \\
\text { [botany] } \\
\text { (puudub) } \\
\text { [photography] } \\
\text { [space] }\end{array}$ & $\begin{array}{l}\text { erialamärgendid on } \\
\text { asendatud }\end{array}$ \\
\hline
\end{tabular}




\begin{tabular}{|c|c|c|}
\hline $\begin{array}{l}\text { folly .. • dekoratiivne pargirajatis } \\
\text { 18. s. }\end{array}$ & $\begin{array}{l}\text { folly .. [architecture] dekoratiivne } \\
\text { pargirajatis } \underline{1 \mathrm{~s}} \text {. }\end{array}$ & $\begin{array}{l}\text { programm on (punk- } \\
\text { tiga) numbrit pidanud } \\
\text { tähendusnumbriks ( } 8 . \text { ) } \\
\text { ja eemaldanud }\end{array}$ \\
\hline $\begin{array}{l}\text { grit .. • pulber kõvadest osakestes } \\
\text { suurusega üle } 76 \underline{\mu \mathrm{m}}\end{array}$ & $\begin{array}{l}\text { grit .. [technics] pulber kõvadest } \\
\text { osakestest suurusega üle } 76 \underline{m}\end{array}$ & $\begin{array}{l}\text { esimene sümbol (kree- } \\
\text { ka täht) on numbri } \\
\text { järel kustutatud }\end{array}$ \\
\hline $\begin{array}{l}\text { singles .. • kivimitükk: katusekilt } \\
12 \times 8 \text { tolli, süsi } 1-\underline{0,5 \text { tolli }} \\
\text { X-band .. • X-laineala: 1. sage- } \\
\text { dusriba } 8 \ldots 12 \mathrm{GHz} \text {; } 2 \text {. radarite } \\
\text { tööriba } 8,8 \ldots 10,68 \mathrm{MHz}\end{array}$ & $\begin{array}{l}\text { singles .. [mineralogy] süsi 1- } \underline{0} \\
\text { X-band [technics] radarite töö- } \\
\text { riba } \underline{8}\end{array}$ & $\begin{array}{l}\text { programm on pida- } \\
\text { nud numbris esinevat } \\
\text { koma vastete eralda- } \\
\text { jaks, mida inimtoime- } \\
\text { taja kunagi ei teeks }\end{array}$ \\
\hline
\end{tabular}

Sellele, et FESTART-sõnaraamatu tegemisel võib olla kasutatud TEA teaduse ja tehnika sõnaraamatu elektroonilist põhja, osutavad taas TEA teksti vigased kohad (nt madalatemperatuurne, pinuase nõlv jt), mis parandati enne TEA teaduse ja tehnika lisaköite ilmumist (madalatemperatuuriline, pinnasenõlv jt). Samad vead on aga FESTART-sõnaraamatus täiesti olemas. Ekspertiisi käigus leiti ka selliseid kattuvaid kirjavigu, mida lisaköite tegemisel veel polnud märgatud (harkelunieemaldus pro harkelundieemaldus jt).

\section{3. Üldsõnavara}

Pärast kahest eelnevast allikast (TEA inglise-eesti majandus, TEA teadus ja tehnika) pärinevate MV-gruppide eemaldamist jäi alles umbes pool esialgsest mahust (35 298 märksõna, 48 ooo MV-gruppi). Järgnevalt võrreldi seda materjali üldkeelt esindava TEA Passwordiga (23 629 märksõna, sh allmärksõnad - tuletised ja väljendid), kus iga tähenduse puhul on vasteid esitatud harilikult üks, harvemini kaks-kolm. Kuna eksperdid kahtlustasid TEA Passwordi ülevõtmist juba varem ilmunud kirjastuse Festart elektroonilisse sõnastikku (FESTART Keyword), siis lubati viimast kasutada täiendava võrdlusmaterjalina.

FESTART Keyword koosneb Festardi sõnastikele iseloomulikult hästi eristuvast majanduse- ja üldsõnavara osast. Lihtne analüüs annab alust oletada, et vähemalt kolmveerand FESTART Keywordi mittemajandussõnadest on üle võetud TEA Passwordi elektroonilisest põhjast. Kopeeritud on tervikartiklid, st peale märksõnade ja vastete ka hääldused, seletused ja näitelaused. Eespool juba mainitud 69 TEA Passwordi poolitusveast 68 “esindatus" FESTART-sõnaraamatus kordub ka siin, ajaliselt varasemas Keywordis. Võrdluse käigus erinevaks tunnistatud artiklites on erinevused põhjustatud hääldusmärkide erinevast kodeeringust jt vormistuslikest erinevustest (näiteks punkt iga artikli ja iga tähenduse lõpus, vt tabel 7), mida kuigi tõsiselt ei saa võtta. Eksperdid ei pidanud täpsemat kvantitatiivset analüüsi tarvilikuks, vaid pidasid tõendusmaterjaliks sisulisi (kvalitatiivseid) andmeid. Kuna TEA Passwordi korrektuur ja küljendus on olnud korrektne, siis leidub ka väga vähe trükivigu, millele toetuda. 
Tabel 7. Festart Keywordi võrdlus TEA Passwordiga

\begin{tabular}{|c|c|c|}
\hline TEA Password & FESTART Keyword & Selgitus \\
\hline $\begin{array}{l}\text { keep away to (cause to) remain } \\
\text { at a distance: Keep away -- it's } \\
\text { dangerous! • eemale hoidma }\end{array}$ & $\begin{array}{l}\text { keep away to (cause to) remain } \\
\text { at a distance: Keep away - it's dan- } \\
\text { gerous! • eemale hoidma. }\end{array}$ & $\begin{array}{l}\text { lisandus: punkt } \\
\text { artikli lõpus }\end{array}$ \\
\hline $\begin{array}{l}\text { keep back } 1 \text { not to (allow to) } \\
\text { move forward: She kept the child } \\
\text { back on the edge of the crowd; } \\
\text { Every body keep back from the } \\
\text { door! - eemal hoidma } \mathbf{2} \text { not to tell } \\
\text { or make known: I feel he's keeping } \\
\text { the real story back for some reason } \\
\text { - enda teada hoidma }\end{array}$ & $\begin{array}{l}\text { keep back } \mathbf{1} \text { not to (allow to) } \\
\text { move forward: She kept the child } \\
\text { back on the edge of the crowd; } \\
\text { Every body keep back from the } \\
\text { door! • eemal hoidma. } \mathbf{2} \text { not to tell } \\
\text { or make known: I feel he's keeping } \\
\text { the real story back for some reason. } \\
\text { - enda teada hoidma. }\end{array}$ & $\begin{array}{l}\text { lisandus: punkt iga } \\
\text { tähenduse ja artikli } \\
\text { Iõpus; } \\
\text { viga: p.o everybody } \\
\text { (viga pärineb TEA } \\
\text { Passwordist, kus } \\
\text { rea lõpust puudub } \\
\text { poolitusmärk, mida } \\
\text { asendab tühik) }\end{array}$ \\
\hline $\begin{array}{l}\text { aggressively } \\
\text { appreciatively } \\
\text { comprehensively }\end{array}$ & $\begin{array}{l}\text { aggressively } \\
\text { appreciatively } \\
\text { comprehensively }\end{array}$ & ilma häälduseta \\
\hline $\begin{array}{l}\text { mechanic .. • mehhaanik } \\
\text { mechanical .. • mehhaaniline } \\
\text { mechanically .. • mehhaaniliselt }\end{array}$ & $\begin{array}{l}\text { mechanic mehaanik } \\
\text { mechanical mehaaniline } \\
\text { mechanically mehhaaniliselt }\end{array}$ & $\begin{array}{l}\text { ebajärjekindlus } h / h h \\
\text { tarvituses }\end{array}$ \\
\hline
\end{tabular}

Sellegipoolest on võimalik analüüsida (ja hinnata) kõigile sõnastikele omaseid parameetreid nagu sõnavalik, hääldused, vastete kokkulangevused, lisamärgendite kasutamine, artikli struktuur jm.

TEA Passwordis on lihtmärksõnu (vastandina mitmeosalistele) 18 647, neist 17912 (96\%) leidub FESTART-sõnaraamatus. Sõnastike sarnast tüüpi ja võrreldavat mahtu arvestades on see ootuspärane tulemus. MV-gruppe on TEA Passwordis kokku 31 391, millest 21 632-le (69\%) leidub täpne paariline FESTART-sõnaraamatus. Samas puudub FESTART-sõnaraamatust umbes 8000 TEA Passwordi MV-gruppi (25\% lihtmärksõnadest, nt keenness 'ind', kidnap 'inimest röövima' jt). Ebatäielikule kattumusele vaatamata võib FESTART-sõnaraamatust leida kokkulangevusi, mis endiselt seovad teda TEA Passwordi sisuga (haruldased vasted), nagu ka elektroonilise põhjaga (küljendusest pärit poolituskriipsud).

Üht osa TEA Passwordi märksõnadest - mis a) on ilma häälduse ja sõnaliigita, ja b) pole pärit TEA teaduse ja tehnika sõnaraamatust (kokku 1141) - võrreldi täiendavalt EKI sõnastikuga. Kui MV-gruppide kokkulangevus TEA ja FESTARDI vahel oli 97\%, siis TEA ja EKI vahel ainult 53\% (!). Kui TEA sõnaliigimärgendit sisaldavad MV-grupid kattusid FESTART-sõnaraamatuga 92\% ulatuses, siis EKI-ga üksnes $24 \%$. Need võrdlevad andmed võiksid olla kõnekas argument sõnaraamatu originaalsuse tõestamisel.

Kuna ekspertidele torkas pidevalt silma FESTART-sõnaraamatu heterogeensus, mis andis alust arvata, et sellegi allesjäänud materjali saamiseks on mehaaniliselt ühendatud mitu allikat, siis võrreldi materjali ka Silvet 1989 sõnaraamatuga. Kahtlus, et ülejäänud materjal FESTART-sõnaraamatus pärineb Silvet 1989 sõnaraamatust, leidis kinnitust. Sellele viitab mitu asjaolu. Esiteks, peaaegu kõik eesti vasted järelejäänud FESTART-sõnaraamatu materjalis esinevad täpselt samas järjestuses Silvet 1989 vastete hulgas. Teiseks, leidub vasteid, mille tarvitus on ebaharilik, nüüdiskeeles vananenud ja mis ei esine ei tavakeeles ega üheski muus 
sõnaraamatus, nt adobe - plonnhoone, brief - kohtule esitatav kaitse-kokkuvõte, tight - pinguline, bridle - pahandudes pead üles ning lõuga tagasi tõmbama jpt. Kolmandaks, sellise silmale märkamatu elemendi nagu (elektroonilises versioonis) tühik põhimärksõnaartikli lõpus leiame täpselt nendest kohtadest, kus Silvet 1989 on esitanud sulgudes kommentaare. Tühik - mis elektroonilisel kujul muutub "nähtavaks" - jäi artikli lõppu tõenäoliselt pärast seda, kui sulgudes olnud tekst kustutati (17). Sisuline viga tekkis samal põhjusel (sulgudes osad jäeti mehaaniliselt kõrvale): nõnda sugenes artiklisse kaks identset vastet (18b).

(17a) adulterer abielurikkuja (mees) ～[Silvet 1989]

(17b) adulterer abielurikkuja_ [FESTART-sõnaraamat]

(18a) current vool, voolus, (mere)hoovus, (elektri)vool [Silvet 1989]

(18b) current vool, voolus, hoovus, vool [FESTART-sõnaraamat]

Ekspertide hinnangul on Silvet 1989 vastete suurest hulgast (umbes 150 ooo MVpaari) üle võetud umbes kolmandik. Vastete ülevõtmise kopeerimise teel välistab asjaolu, et 1999. aastal polnud sõnastiku elektroonilist varianti veel olemas: nii on osa kirjavigu tekkinud teksti sisestamisel (nt silmamoondusrikke pro silmamoondustrikke). Et FESTART on ka omalt poolt vasteid lisanud, sellele viitavad leitud vigased märksõnad või vasted, mis sellisena mujal ei esine (nt märksõna thunderstruc pro thunderstruck, vaste $\underline{\text { äärmuste }}$ abinõude pro äärmuslike abinõude).

\subsection{Teise ülesande vastus}

FESTART-sõnaraamatu majandussõnavara pärineb tõenäoliselt täielikult TEA inglise-eesti majandussõnaraamatust, olles peitva vaheastmena üle võetud varasemast FESTART inglise-eesti majandussõnaraamatu arvutiversioonist. Majandussõnavara osakaal kogu sõnaraamatus on 23\% (vt tabel 9).

FESTART-sõnaraamatu tehnikasõnavara pärineb tõenäoliselt TEA teaduse ja tehnika sõnaraamatus, kust on üle võetud ligi 20000 MV-gruppi. Tehnikasõnavara osakaal kogu sõnaraamatus on $16 \%$ (vt tabel 9).

FESTART-sõnaraamatu üldsõnavara pärineb kahest allikast: TEA Passwordist (400o MV-gruppi) ja Silvet 1989-st (hinnanguliselt 69 ooo MV-gruppi). Üldsõnavara osakaal kogu sõnaraamatus on $59 \%(3 \%+56 \%)$ (vt tabel 9$)$.

FESTART-sõnaraamatu originaalloomingu suuruseks on hinnanguliselt $2 \%$ (vt tabel 9). 
Tabel 9. Eri sõnastike osakaal FESTART-sõnaraamatus

\begin{tabular}{|l|l|r|c|}
\hline Sõnavararühm & Võrdlusobjekt & $\begin{array}{c}\text { FESTART-sõnaraamatuga } \\
\text { kattuvate MV-gruppide } \\
\text { arv }\end{array}$ & $\begin{array}{c}\text { Osakaal (\%) } \\
\text { FESTART-sõna- } \\
\text { raamatus }\end{array}$ \\
\hline $\begin{array}{l}\text { Majandus-sõna- } \\
\text { vara }\end{array}$ & $\begin{array}{l}\text { TEA inglise-eesti } \\
\text { majandus }\end{array}$ & ligi 28000 & $23 \%$ \\
\hline Tehnika-sõnavara & TEA teadus ja tehnika & üle 20 000 & $16 \%$ \\
\hline Üldsõnavara & TEA Password & 4000 & $3 \%$ \\
\cline { 2 - 4 } & Silvet 1989 & $\begin{array}{r}\text { (umbkaudne hinnang:) } \\
69000\end{array}$ & $56 \%$ \\
\cline { 2 - 4 } & $\begin{array}{l}\text { Kirjastuse FESTART } \\
\text { omalooming }\end{array}$ & $\begin{array}{r}\text { (umbkaudne hinnang:) } \\
\text { pisut üle 2 000 }\end{array}$ & $2 \%$ \\
\hline FESTART-sõnaraamatus kokku & 122915 & $100 \%$ \\
\hline
\end{tabular}

\section{Kolmas ülesanne: võimalik koostamisskeem}

Eksperdid, kes lähtusid kirjastuse Festart väitest, et vaidlustatud FESTART-sõnaraamatu koostamine algas FESTART inglise-läti sõnastiku põhjalt, pakkusid välja järgmise skeemi:

1) aluseks võeti märksõnastik ja hääldused FESTART inglise-läti sõnastikust, jättes välja mitmest sõnast koosnevad märksõnad;

2) jaotus sõnaliikideks võeti tõenäoliselt koos vastetega üle Silvet 1989 sõnaraamatust;

3) koostajad said tõenäoliselt ülesande lisada Silvet 1989 põhjal nii palju vasteid, kui nad tarvilikuks peavad;

4) nii valmis sõnastik, mille maht oli vähemalt 32 ooo märksõna (koos häälduste, sõnaliikide ja erialamärgenditega). Sellele tehti pealiskaudne korrektuur;

5) saadud sõnastikku täiendati puuduvate märksõnade ja vastetega TEA Passwordist: programmiga nopiti välja ühesõnalised märksõnad ja nende vasted. Tekkisid esimesed ebaühtlused: osa märksõnu varustati nii häälduse kui ka sõnaliigiga, osa ainult sõnaliigiga, osa üksnes eesti vastega. Märksõnade arv kasvas 3000 võrra (kokku 35 ooo);

6) seejärel täiendati sõnastikku tõenäoliselt TEA teaduse ja tehnika sõnaraamatust pärit märksõnade ja vastetega (välja jäeti mitmest sõnast koosnevad märksõnad). Märksõnade arv kasvas üle 13 ooo võrra (kokku üle 48 ooo). Erialamärgendite ühtlustamisel programmidega tekkis läbivaid vigu;

7) saadud sõnastikule lisati tõenäoliselt kogu FESTART inglise-eesti majandussõnaraamat (27 500 märksõna - mis omakorda oli üle võetud TEA inglise-eesti majandussõnaraamatu küljenduspõhjast). Kõik need lisatud märksõnad moodustasid eraldi üksuse (seetõttu esineb korduvaid märksõnu);

8) sõnastik sai oma lõpliku kuju: valminud FESTART-sõnaraamatus on 71154 märksõna. 


\section{Neljas ülesanne: kas tegemist on originaal- või tuletatud teosega?}

Plagiaatlus selle sõna laiemas tähenduses on sõnastike koostamisel vältimatu. Ühtki sõnastikku ei koostata nullist ja mis tahes uue sõnastiku autor saab materjali olemasolevatest sõnastikest. Kui selle tegevuse käigus a) viidatakse algallikatele, b) omandatakse litsentsiluba, ja c) luuakse loominguliselt iseseisev ja algsest teosest sõltumatu teos - siis on (autoriõiguse sõnastuses) tegemist tuletatud teosega, mida plagiaatluseks ei nimetata.

FESTART-sõnaraamatut ei pea eksperdid originaalsõnastikuks, sest ekspertiisi tulemused näitavad, et selle materjal on mehaaniliselt kokku kuhjatud neljast sõnaraamatust. Kirjastuse Festart omapoolne, st originaalne panus on ainult $2 \%$. Sellise mehaanilise ülevõtmise puhul ei tohiks autoriõiguste rikkumise üle otsustamisel saada määravaks asjaolud, et alusmaterjali ei võetud üle tervikuna (Silvet 1989 vastetest on kirjutatud ümber kolm viiendikku, TEA Passwordist viiendik, TEA teaduse ja tehnika sõnaraamatust umbes kolmandik) või et saadud sõnastik ei koosne enam ühest, vaid mitmest eri allikast. Juba algsõnastikele viitamata jätmine on käsitletav autoriõiguse rikkumisena, seda ka juhul, kui on leping, mis lubab nimetatud teoseid kasutada (AÕS $\S 35 \lg 3$ ).

Autorikaitse objektiks saab olla terviklik teos/andmekogu, sõnastike puhul on võimalik asuda seisukohale, et autorikaitse alla peaks kuuluma autori lisatud loominguline panus, mis võib väljenduda märksõnavalikus, sõnastiku ülesehituses, uute vastete, definitsioonide, kasutusnäidete, kommentaaride, illustratsioonide jm lisamises vm viisil. Vaidlustatud sõnaraamat ei vasta ühelegi neist kriteeriumeist. Koostajate tegevus on mõnevõrra märgatav vaid majandussõnavara puhul.

Kõige selle põhjal on eksperdid FESTART-sõnaraamatu nimetanud tuletatud, mitte originaalteoseks. Autoriõiguse seaduse järgi on tuletatud teos “... teose tõlge, algse teose kohandus (adaptsioon), töötlus (arranžeering) ja teose muu töötlus." (AÕS $\S 4 \lg 21$ )

\section{Lõpetuseks: oportuniteedist}

Kuigi ekspertiis tõestas üsna üheselt vaidlustatud sõnaraamatu mehaanilise kompileerimise käigu, ilma selleks luba omamata, lõpetati kriminaalasi, mida Eesti õigussüsteemis oli menetletud seitse aastat, 2007. aastal oportuniteedi alusel (Truu 2007). Mida selle all mõista? Aga seda, et riigi toimimises, nagu iga inimese elus, arvatakse mõned sündmused, teod või probleemid vähem oluliseks kui teised: oportuniteediprintsiip on põhimõte, mis seadusena võimaldab otsustada riigi asjade otstarbekuse üle.

Eesti Vabariigi kriminaalkoodeksisse lisandus oportuniteedipunkt (KrMS $\S 168$ täiendusena) uuesti 2004. aastal. ${ }^{11}$ Oportuniteedi põhiline mõte ongi olnud eelkõige vähendada politseiuurijate, prokuröride ja kohtute koormust, st lubada otsustada juba alamal astmel. Kriminaalmenetluse võib oportuniteedile toetudes lõpetada, kui puudub avalik menetlushuvi ja kui süü ei ole suur (KrMS § 168, 202) või kui karistus on ebaotstarbekas (KrMS § 168, 203). Prokurör Endla Ülviste on

11 Nõukogude koodeksis oli see samuti olemas, ja toimis väga hästi, nagu on kinnitanud Ain Seppik, kelle 
küll väljendanud oma kergendust: "Te ei kujuta ette, kui palju on kohtutes neidsamu pasteetide, õllepudelite ja saiakeste lugusid" (Püüa 2004). Samas jääb kummitama võimalus "teise astme kuritegu niiöelda lämmatada" ${ }^{12}$ Ja kuidas ikkagi mõõta avalikkuse huvi? Kas lugeda kokku ajakirjanduses avaldatud kirjutised? Või asjasse segatud inimeste hulk? Või veel muud moodi? 2007. aastal avaldatud kokkuvõttest selgub, et lõviosa kriminaalmenetlustest ongi lõpetatud avaliku huvi puudumise tõttu (92\% ehk 5239 kriminaalasja), vähem on toetutud ebaotstarbeka karistuse sättele ( $8 \%$ ehk 465 juhtu). ${ }^{13}$

Ehmatava ja kurvastava tõsiasjana lisandus 2007. a sellesse pasteedi-õllepudeli-saiakeste loendisse ka loometöö vili - sõnaraamat -, ja samuti avaliku huvi puudumise tõttu. Päris karistuseta vaidlustatud sõnaraamatu tegijad siiski ei jäänud: Harju maakohus otsustas, et S. Gluhhov peab riigi tuludesse tasuma 125000 krooni ning tegema 100 tundi üldkasulikku tööd, firma Festart peab maksma riigi tuludesse 250 ooo krooni, tasuma kriminaalmenetluse kulud (413 682 krooni) ja kannatanu TEA Kirjastuse kulud (216 889 krooni).

\section{Ettepanek tuleviku jaoks}

Eesti Keele Instituudis välja töötatud sõnastike kokkulangevust hindava märksõna-vaste-gruppide mõõtmise meetodi ja selle rakendamise põhjal kakskeelsete sõnaraamatute ekspertiisil tuleks kehtestada piirmäär, millest edaspidi lähtuda sõnaraamatu originaalsuse üle otsustamisel.

Tuletame veel meelde siinsest artiklist läbi käinud protsente ja fakte: 18 . saj inglise Fisheri õigekirjasõnaraamat, kus üks-ühele oli teisest üle võetud 43,5\%, lubati kohtuvaidluste järel siiski välja anda; teise, 17. saj inglise juhtumi puhul olevat üle võetud koguni 70\% märksõnadest koos vastetega, aga too asi kohtuni ei jõudnud. FESTART inglise-eesti majandussõnaraamatu MV-gruppidest langes TEA majandussõnaraamatu materjaliga kokku 97\%. Ühe kontrollrühma (1141 märksõna) osas oli FESTART-sõnaraamatu kokkulangevus TEA Passwordiga samuti 97\%, samas EKI sõnastikuga 53\%. Kui samas kontrollrühmas võeti arvesse kolmas üksus (sõnaliigimärgend), siis kattusid MV-grupid TEA-ga 92\%, aga EKI sõnastikuga üksnes $24 \%$ (!) ulatuses. Korduva märksõna-osisega artiklitest (ligi 5000) on FESTART-sõnaraamatus 90\% selliseid, kus märksõna kordub muutumatul kujul. Ekspertiisi käigus leitud 69-st TEA Passwordi poolitusveast kordub 68 (98,5\%) FESTART-sõnaraamatus.

Autorite ettepanek on kehtestada kahes sõnaraamatus kokkulangevate märksõna-vaste-gruppide piirmääraks umbes $60-75 \%$ (pöörates muidugi tähelepanu ka muudele "arvutinippidele"). Üle selle on tegemist plagiaadiga, alla selle (tuletatud) originaalteosega.

12 Märt Raski sõnad Riigikogu õiguskomisjoni istungil (väljavõte protokollist 23.10.2003).

13 Justiitsministeeriumi kriminaalpoliitika osakonna ülevaade, ptk "Kriminaalmenetluse oportuniteediga lópetamine (1.07.2004-31.03.2007)", vt www.just.ee (6.10.2007). 


\section{Kirjandus}

Arujärv, Evi 2008. Kultuur - missioon ja äri. - Eesti Päevaleht, 15.02.2008.

AÕS = Autoriõiguse seadus. Elektrooniline Riigi Teataja, https://www.riigiteataja.ee/ert/ act.jsp?id=12791124 (20.02.2008).

Cormier, Monique C.; Fernandez, Herberto 2005. From the Great French Dictionary to the Royal Dictionary. - International Journal of Lexicography, Vol. 18, No. 4, 479-507.

EEVA $=$ Ross, Kristiina. Anton Thor Helle (1683?-1748). Piiblitõlkija ja eesti kirjakeele arendaja, Jüri pastor. - Eesti vanema kirjanduse digitaalne tekstikogu. www.utlib.ee/ekollekt/eeva/ (20.11.2007).

Helle, Anton Thor 1732. Kurtzgefaszte Anweisung Zur Ehstnischen Sprache, in welcher mitgetheilet werden I. Eine GRAMMATICA. II. Ein VOCABULARIUM. III. PROVERBIA. IV. AENIGMATA. V. COLLOQUIA. Tallinn: Eestimaa Konsistooriumi kirjastuskassa.

Hupel, August Wilhelm 1780. Ehstnische Sprachlehre für beide Hauptdialekte, den revalschen und dörptschen, nebst einem vollständigen Wörterbuch. Riga-Leipzig: Hartknoch.

Kask, Arnold 1955. S. H. Vestringi eesti-saksa sõnaraamat ja selle osa eesti leksikograafias. - Ajaloo-keeleteaduskonna töid. Tartu Riikliku Ülikooli toimetised 38. Tartu: Tartu Riiklik Ülikool, 181-192.

Krikmann, Arvo 1986. Fraseoloogiline aines eesti vanemais grammatikates ja sõnastikes. Tallinn: Valgus.

KrMS = Kriminaalmenetluse seadustik. Elektrooniline Riigi Teataja, https://www.riigiteataja. ee/ert/act.jsp?id=12897094 (20.02.2008)

Landau, Sidney I. 2001. Dictionaries: The Art and Craft of Lexicography. 2nd. ed. Cambridge University Press.

McMenamin, Gerald R. 2002. Forensic Linguistics. Advances in Forensic Linguistics. CRC Press.

Püüa, Marko 2004. Pasteedivaraste karistused leevenesid. - Postimees, 25.03.2004. Vt ka http://www.postimees.ee/260304/esileht/siseuudised/129949.php (5.03.2008).

Rodriguez-Alvarez, Alicia; Rodriguez-Gil, Maria 2006. John Entick's and Ann Fisher's Dictionaries: An Eighteenth-century Case of (Cons)Piracy? - International Journal of Lexicography, Vol. 19, No. 3, 287-319.

Truu, Aet 2007. Kohus lõpetas piraatkoopiate valmistamises süüdistatava kriminaalasja oportuniteedi alusel. - Äripäev, 04.04.2007. Vt ka http://www.ap3.ee/Default2. aspx?ArticleID=5aa5daae-8403-4fco-a6b2-17848c1adfc3 (5.03.2008).

Vestring, Salomo Heinrich 1998 [käsikiri ?1720-ndad]. Lexicon Esthonico Germanicum. Trükki toimetanud Ellen Kaldjärv. Tartu: Eesti Kirjandusmuuseum.

Williams, John 1992. The question of plagiarism and breach of copyright in the dictionarymaking process (with particular reference to the UK). - EURALEX '92 Proceedings. Tampere: Tampereen Yliopisto, 561-570.

Margit Langemets (Eesti Keele Instituut) on Iõpetanud Tartu Ülikooli eesti keele ja kirjanduse erialal. Osales TEA-Festardi kohtuprotsessis tunnistajana. Uurimisvaldkonnad: leksikoloogia ja leksikograafia üldiselt, arvutileksikoloogia, leksikaalne semantika.

margit@eki.ee

Piret Voll (Eesti Keele Instituut) on lõpetanud Tartu Ülikooli eesti keele ja kirjanduse erialal. Osales TEA-Festardi kohtuprotsessis peaeksperdina. Uurimisvaldkonnad: leksikolooogia ja leksikograafia. piret.voll@eki.ee 


\section{LINGUISTIC FORENSIC ANALYSIS OF A DICTIONARY: AN ESTONIAN PRECEDENT}

Margit Langemets, Piret Voll

Institute of the Estonian Language

In 2003 the first linguistic forensic assessment of lexicographic objects took place in Estonia. The case required expert assessment of the contents of several dictionaries involved in criminal accusation of theft of intellectual property. The article describes the process of lexicographic expert assessment carried out at the Institute of the Estonian Language, and the ad hoc language-technological method applied. Relying on the results, a critical measure has been elaborated to judge over the degree of originality of bilingual dictionaries. Being the first and only case of its kind in Estonia, it offers a linguistic-forensic precedent.

Keywords: forensic linguistics, lexicographic expert assessment, dictionaries, English, Estonian 